\title{
FACTORS INFLUENCING CONSUMER BEHAVIOUR OF GENERATION $Y$ ON THE CZECH WINE MARKET
}

\author{
Jana Němcová, Pavla Staňková
}

\section{Introduction}

According to Tibor Nyitray, President of the Wine Growers' Union of the Czech Republic, wine is not only a product of nature, but also pleasure and joy, work and entrepreneurship, the result of long-term education and practise, the reason for meetings and association, and finally science and trade. Wine and winegrowing has made considerable progress in the last twenty years. Legislation has improved, the quality of equipment has risen, modern technologies have been developed, and a significant number of wines have obtained remarkable achievements at international competitions. Everything now depends on winemakers. They should not 'only' sell the wine that produce, but they should seek to build a good reputation for their products, gain the permanent confidence of consumers, and offer interesting and attractive wines. It is important that they will be more interested in what wines customers want to receive from them, and their aim should be in the first instance to satisfy consumers, and only after sales (Bárta, 2013).

Wine is becoming a lifestyle beverage, and this is reflected in statistics in the UK, USA, Australia and other countries (Bruwer et al., 2011). The wine industry in Australia and New Zealand has made significant growth and changes and in the last ten years, the number of wineries in these countries has increased substantially (Treloar et al., 2004). The Czech Republic is also one of the countries with increasing consumption of wine. While consumption of beer, the popular drink of the Czechs, is slowly declining, wine has an increasing trend in the long term.

The results of the latest survey of the Wine Fund of 2016 shows that most consumers in the Czech Republic prefer Moravian and Bohemian wines (53\% of respondents), which they consider better compared to foreign competitors.
Only $8 \%$ of respondents prefer imported wines, while other respondents were not identified in their answer. Similarly, consumers perceive the quality of domestic wines where $43 \%$ of respondents assess Moravian and Bohemian production as better. It can be stated that the more frequently consumers domestic or foreign wine consume, the more they appreciate the quality of Moravian and Bohemian wines (Straková, 2017).

Winemakers should focus their efforts on young consumers entering the wine market with significant purchasing power. The young generation is rapidly adopting wine as its preferred beverage and therefore constitutes the potential consumer segment that can soon increase the wine consumption (Chrysochou et al., 2012). Young customers belonging to Generation $Y$ are referred to as wine consumers of the future and are increasingly important for the global wine industry. They are considered to be the next 'hero' generation with greater purchasing power than their parents. In order to support growth of the wine industry, it is therefore important to understand the buying behaviour and motives of the purchasing decisions of this young consumer segment (VinIntell, 2013).

This article deals with the buying behaviour of young consumers on the wine market. The main aim of this paper is to identify the factors influencing the purchasing decision of the customer Generation $\mathrm{Y}$ in the selection of wine in the Czech Republic. Generation $Y$ is narrowed down to the group of young people aged $18-25$ on that matter. The article consists of the following chapters: the first chapter describes the theoretical basis in matters of buying behaviour and Generation $Y$, the second chapter focuses on the research objective and methodology, the research results dealing with the factors influencing consumers in 
the selection of wine are defined in the third chapter, the fourth chapter discusses the findings of the research results, and the final chapter summarizes the findings and sets out the article limitations and recommendations for further research.

\section{Theoretical Background}

Kotler and Armstrong (2016) define consumer buyer behaviour as 'the buying behaviour of final consumers - individuals and households that buy goods and services for personal consumption'. It is therefore such behaviour that can be tracked in searching for, purchasing, using, evaluating and disposing of the products and services that will meet their needs. Consumer behaviour deals with these issues: what consumers buy, when they buy it, where they buy it, why they buy it, how often they buy it, how often they use it, how they subsequently evaluate it after the purchase or use, the impact of such evaluations on the future consumers' purchasing decisions, and how they dispose of products or services (Schiffman et al., 2014).

Schiffman et al. (2012) state that consumer behaviour has changed significantly in the last few decades. The main cause is the internet, which makes people increasingly buying on e-shops, selling their things via online auctions and have access to a great deal of different information. Progress in digital technology allows television viewers to avoid advertising using the skip function. These modern ways of selling exist today thanks to understanding of consumer behaviour and identifying their needs. Lockshin and Hall (2003) deal with wine consumption behaviour and wine marketing. They emphasise that if marketers understand consumers' decision-making process when choosing wine, they will be better able to decide on prices, packaging, distribution, advertising or retail merchandising strategies.

According to Gunay and Baker (2011), it is very important to understand the factors influencing consumers' behaviour. The reason is to keep not only existing customers but also to attract new ones and gain a competitive advantage in the market. Recognizing consumers' wants and needs will help firms to identify what to produce to satisfy customers' requirements better than competitors. Kotler and Keller (2016); Kotler and Armstrong (2016) mention three factors influencing consumer behaviour. These include cultural (culture, subculture, social class), social (groups, family, social roles and statuses), personal (age, lifecycle stage, occupation, economic situation, lifestyle, personality, self-concept) and psychological factors (motivation, perception, learning, beliefs and attitudes).

And because customers have different needs and wants, it is necessary to divide the market into relatively homogeneous groups. Schiffman et al. (2012) define market segmentation as 'the process of dividing a market into distinct subsets of consumers with common needs or characteristics and selecting one or more segments to target with a distinct marketing mix'. There are many segmentation criteria, but the major segmentation variables are geographic, demographic, psychographic and behavioural (Solomon et al., 2010). In the context of this article, only the demographic criterion will be mentioned here. Lake (2009) argues that demographic segmentation divides the market into segments based on age, gender, education, ethnicity, occupation, life-cycle stage and income. Kotler and Armstrong (2016) complement these characteristics with religion and generation. As claimed by Schiffman and Wisenblit (2015), age is one of the most important factors in marketing. The essence of this segmentation is dividing consumers into different age categories (e.g. under 18, 18-34, 35-46, 47-56, etc.). Customers' needs are often different, and age influences their buying preferences. Many marketers are currently examining the needs of 18 to 34 year old consumers who are called Millennials. Gender segmentation is commonly used in the field of cosmetics, magazines, toys, clothing, and toiletries (Kotler \& Armstrong, 2016). The behaviours and tastes of men and women are constantly changing, so it is very interesting to examine this segmentation criterion. For example, in the past, it was assumed that men decide on car purchase, but this is changing with time. (Solomon et al., 2010) Gender segmentation is also important in the decisionmaking process when choosing wine. There are many wines of different tastes and qualities in the market, and it is necessary to find out how the consumer chooses a certain wine. Therefore, identifying differences between women and men may be the starting point (Atkin et al., 2007). Schiffman and Wisenblit (2015) consider income as an important segmentation variable, because it shows the 
ability to pay for a product or brand. Income is often associated with age and occupational status. Education, occupation, and income are also closely intertwined, because highlevel occupations producing high incomes are usually built on more professional education and are more prestigious than occupations with a lower level of education.

The next generation of consumers Generation $\mathrm{Y}$ - is an important area of marketing research. This generation cohort represents one of the most promising and a future-oriented wine market segment and is increasingly important as wine consumers (Charters et al., 2011; de Magistris et al., 2011). This statement is also confirmed by Fountain and Lamb (2011), who state that Generation $Y$ are consuming more wine in the everyday occasion than their previous generation when they were of their age. In this context, it is likely that wine consumption could increase and Generation $Y$ will be loyal wine consumers.

Generation Y (also known as Millennials) is generally defined as the generation of young people who were born in the 1980s and 1990s. Regarding the precise definition of the years that should be included within this generation, there are many dissenting views of various experts. But, as Bejtkovský (2016) says, the year of birth is only one of the factors to be considered when defining a given generation. Generations are shaped not only by years but also by history. Schwartz et al. (2016) also lean to this claim and list a generation overview of different countries where the socioeconomic, cultural and political events are taken into account. Specifically, in the Czech Republic, Generation $Y$ is represented by people born in 1983-2000. They are the children of Baby Boomers (born in 1946-1964) and Generation $X$ (so-called Husak's children generation, who were born in 1965-1982). Doyle (2011) argues that a characteristic attribute of Millennials is their dependence on technologies and their need for constant interaction with these technologies. Bencsik et al. (2016) also perceive this young cohort, whose name ' $Y$ ' comes from the English word youth, as a digital generation that is highly qualified in this area. They live for the present and have no problem to accept changes. Family does not mean everything for them, and traditional values are disappearing from their lives. According to Horváthová et al. (2016), these young people are very ambitious, it is important for them to have freedom and an interesting job full of challenges. They require a higher standard of living and are responsible for their social security. They want to take full advantage of their life opportunities, but they do not wish to sacrifice their personal life. Generation $Y$ is influenced by the recommendations and opinions of friends (on social networks) when buying, unlike their parents and grandparents who were most influenced by advertising.

Consumer behaviour research of Generation $Y$ on the wine market is currently a very topical issue and many authors stress the importance of this matter. Agnoli et al. (2011) state that in relation to the consumption behaviour of the young Generation Y, wine and its elements influencing the choice of wine as compared to other alcoholic beverages are an unexplored area. There are several foreign authors dealing with buying behaviour of Generation $Y$ on the wine market. However, only very limited number of scientific research have been done on the Czech market on this issue. Some authors address the buying behaviour of Generation $Y$ but do not apply this issue to the wine market (e.g. Klapilová Krbová, 2016). Other authors examine wine buying behaviour but focus on all generations (e.g. Anchor \& Lacinová, 2015; Chládková, 2015). Research on wine buying behaviour and Generation $Y$ in the Czech Republic is then expressly dealt with Veselá and Zich (2015) who examine the country of origin effect and its influence on the consumer behaviour of Generation $Y$ in the Czech Republic. The fact is that current research carried out at The Faculty of Management and Economics of Tomas Bata University in Zlín looks at this consumer behaviour issue on a much more comprehensive point of view and addresses the literary gaps on Generation $Y$ and wine in the Czech Republic. Specifically, the individual factors (such as label design, the information on a label, bottle shape, bottle colour, price, etc.) influencing the buying decision process of the young consumer when choosing wine are examined here. Therefore, for enlargement of scientific literature in this article, attention will be focused on Generation $Y$ and wine consumer behaviour in the Czech Republic. 


\section{Research Objective and Methodology}

On the basis of literary research and consultation with specialist staff of the wine shop in Zlin, a list of factors affecting the decision-making purchase in the wine category was made. This knowledge was used for the compilation of the questionnaire, which was a tool of a pilot study in research on consumer purchasing decision. These are factors such as: colour of wine, label design, the information on a label, bottle shape, bottle colour, type of bottle cap, medals, advertising, price, previous purchase experience, discounts, references from family, friends and acquaintances, recommendations of the wine shop operator or sommelier and store availability.

As already mentioned in the chapter on the theoretical background, many scientific publications deal with consumer buying behaviour and Generation Y. Unfortunately, there are hardly any studies that would examine precisely customers' purchase decisions and Generation $Y$ on the Czech market. Therefore, this article focuses on the still unexplored field, i.e. on the Czech market, and consumer buying behaviour of Generation Y.

The main aim of this article is to identify the factors which have a considerable impact on the customer of Generation $Y$ when choosing wine in the Czech Republic. The essence of the survey is therefore to find out the wine attributes according to which young consumers make their own choices about wine, and to better understand their behaviour. The target group is therefore made up of young people of Generation Y aged 18-25 who drink or at least buy wines. Quantitative research was chosen as the research method, which was made using a questionnaire. The investigation covered the period from February 2017 to September 2017. The total number of respondents was 648 young people.

Four research questions were defined:

$Q_{1}$ : What are the main characteristics of the Generation $Y$ behaviour on the wine market?

$Q_{2}$ : What are the key factors influencing the wine choice of Generation $Y$ ?

$Q_{3}$ : Are there any differences in the key factors influencing the wine choice between men and women of Generation $Y$ ?

$Q_{4}$ : Are there any differences in the key factors influencing the wine choice of the respondents according to their income?
Two hypotheses were defined:

$\mathrm{H} 1_{0}$ : According to the respondents participating in the sample, the mean perception of the key factors influencing the wine choice of Generation $\mathrm{Y}$ for males and females are equal.

$\mathrm{H} 1_{A}$ : According to the respondents participating in the sample, the mean perception of the key factors influencing the wine choice of Generation $Y$ for males and females are not equal.

The formula for the Two-sample t-Test for equal means was used. The formula for the pooled estimator of $\sigma 2$ is

$$
S_{p}^{2}=\frac{\left(n_{1}-1\right) s_{1}^{2}+\left(n_{2}-1\right) s_{2}^{2}}{n_{1}+n_{2}-2}
$$

where $s_{1}$ and $s_{2}$ are the standard deviations of the males and females.

The formula for comparing the means of two populations using pooled variance is

$$
t=\frac{\bar{x}_{1}-\bar{x}_{1}-\Delta}{\sqrt{S_{p}^{2}\left(\frac{1}{n_{1}}+\frac{1}{n_{2}}\right)}}
$$

where equation and equation are the means of the two samples, $\Delta$ is the hypothesized difference between the men and women means ( 0 if testing for equal means), $S_{p}^{2}$ is the pooled variance, and $n_{1}$ and $n_{2}$ are the sizes of the two samples. The number of degrees of freedom for the problem is

$$
d f=n_{1}+n_{2}-2
$$

$\mathrm{H}_{2}$ : In relation to the key factors influencing the wine choice of the respondents there is no difference among income groups.

$\mathrm{H} 2_{\mathrm{A}}$ : In relation to the key factors influencing the wine choice of the respondents there is no difference among income groups.

Hypotheses were tested on the level of significance of $\alpha=0.05$. We used the Pearson's chi-squared $X^{2}$ test of independence for a contingent table, using IBM SPSS Statistics software.

The value of the test-statistic is

$$
\chi^{2}=\sum_{i=1}^{r} \sum_{j=1}^{c} \frac{O_{i j}-E_{j}}{E_{j}}
$$


$\chi^{2}=$ Pearson's cumulative test statistic;

$O_{i}=$ an observed frequency in a given contingency table;

$E_{i}=$ an expected (theoretical) frequency, asserted by the null hypothesis;

$r$ and $c$ are the number of rows and columns in the table, respectively.

\subsection{Determination of the Sample of the Respondents}

The specification of the sample is the following:

648 respondents took part in the questionnaire survey, but only 571 responses could be used as relevant data for the evaluation. Thus, 77 respondents were excluded on the basis of filtering questions (24 respondents did not fall into category 18-25 years, and another 53 respondents did not drink or did not buy wine during the last 12 months). The survey was carried out in written form, and printed questionnaires were submitted to university students, their families, friends and acquaintances. In addition, the survey was conducted electronically using a cloud storage service called Google Drive where the questionnaire was created and then sent by emails to the potential respondents, and using the social network called Facebook. The questionnaire survey was targeted on Generation $Y$ at the age of $18-25$ years. This age category is an important segment in the lucrative college market (Noble et al., 2009).

Tab. 1 shows that 396 women $(69 \%)$ and 175 men (31\%) were of the relevant sample of respondents. With regard to the highest educational attainment, no one of the respondents completed only primary school, $4 \%$ graduated secondary apprentice school, $78 \%$ had high school degree and $18 \%$ of respondents were university educated. Most of the respondents were students $(62 \%)$, then young people employed in part-time (29\%), $7 \%$ of the respondents were employed in full-time,

\begin{tabular}{|c|c|c|c|}
\hline \multicolumn{2}{|c|}{ Sample characteristics } & \multirow{2}{*}{$\begin{array}{c}\text { Number } \\
396\end{array}$} & \multirow{2}{*}{$\begin{array}{r}\% \\
69\end{array}$} \\
\hline Gender & Female & & \\
\hline & Male & 175 & 31 \\
\hline \multirow[t]{4}{*}{ Education } & Less than high school & 0 & 0 \\
\hline & Apprentice school & 22 & 4 \\
\hline & High school degree & 444 & 78 \\
\hline & University degree & 105 & 18 \\
\hline \multirow[t]{5}{*}{ Social status } & Student & 522 & 62 \\
\hline & Employee - full-time job & 57 & 7 \\
\hline & Employee - part-time job & 242 & 29 \\
\hline & Unemployee & 2 & 0 \\
\hline & Self-employed & 15 & 2 \\
\hline \multirow{9}{*}{$\begin{array}{l}\text { Average of the month salary } \\
\text { (CZK) }\end{array}$} & Less than 5,000 & 159 & 28 \\
\hline & $5,000-10,000$ & 120 & 21 \\
\hline & $10,001-15,000$ & 36 & 6 \\
\hline & $15,001-20,000$ & 19 & 3 \\
\hline & $20,001-30,000$ & 19 & 3 \\
\hline & $30,001-40,000$ & 6 & 1 \\
\hline & More than 40,000 & 1 & 0 \\
\hline & Without salary & 183 & 33 \\
\hline & Without answer & 28 & 5 \\
\hline
\end{tabular}


$2 \%$ were self-employed and only 2 respondents were unemployed. According to income, most respondents were in the category without salary (33\%), then $28 \%$ had salary less than CZK 5,000 per month, 21\% earned CZK 5,000-10,000, $6 \%$ fell into the group CZK 10,001-15,000, 19 respondents (3\%) earned CZK 15,001-20,000 per month and this same number of respondents (3\%) also earned CZK 20,001-30,000. Only 6 respondents (1\%) had a monthly salary of CZK $30,001-40,000$. One respondent earned more than CZK 40,000 per month and total of 28 respondents $(5 \%)$ refused to answer.

\section{Research Results}

\subsection{What are the Main Characteristics of the Generation Y Behaviour on the Wine Market?}

In relation to the research results, we can state that the research sample of respondents prefer white wine $(65 \%), 13 \%$ of respondents prefer red wine and $11 \%$ rosé wine. $11 \%$ of respondents do not prefer any colour of wine. Among the most popular varieties of white wine from Generation Y belong Chardonnay (44\%), Palava (44\%), Traminer Rot (33\%), Pinot Gris (33\%) and Sauvignon (22\%). The members of Generation Y prefer these red wine: Blauer Portugieser (28\%), Cabernet Sauvignon (19\%), Merlot (18\%) and Pinot Noir (16\%). According to the opinion of the respondents, $60 \%$ of them have only a general knowledge of wine, $25 \%$ of the respondents present that they have wine minimal awareness, $13 \%$ of these young people have a deeper knowledge of wine and only $2 \%$ have no wine awareness.

Regarding the place of purchase, Generation $Y$ prefers wine shops and supermarkets to the e-shops. The main reasons for the aim of the purchase are meeting with friends (36\%), quiet sitting at home - e.g. food and wine pairing $(33 \%)$ and celebrations (31\%). Regarding wine information sources, the Generation Y respondents use the recommendations from friends and/or relatives as the main source of wine information. The next wine information sources are wine shops, wine cellars and supermarket leaflets.

\subsection{What are the Key Factors Influencing the Wine Choice of Generation Y?}

A five-point Likert scale, ranging from completely agree (1) and completely disagree (5) with influence of factor was used. Generally, we can conclude that the Generation $Y$ respondents perceive as the most important factor for their consumer decision previous purchase experience and references from family, friends and acquaintances. The next important factors are the information on a label, recommendations of the wine shop operator or sommelier, price and colour of wine. The less important factors are bottle shape, bottle colour and advertising, as can be seen from the Fig. 1.

\section{Fig. 1: Factors influencing the wine selection of Generation $Y$}

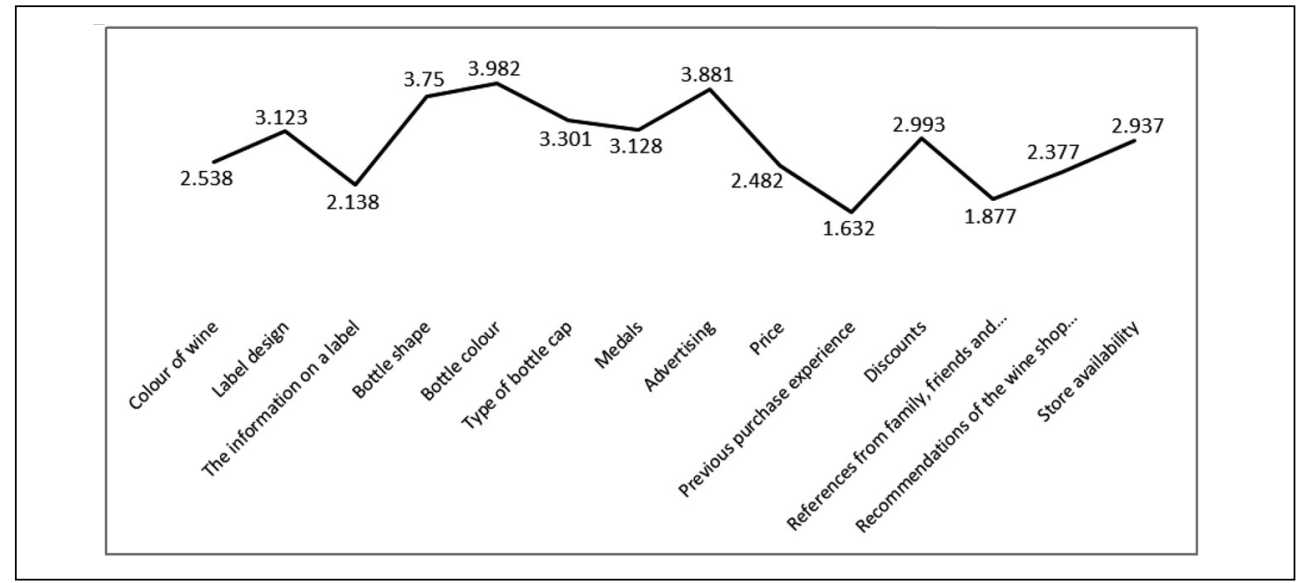




\section{Tab. 2: Group statistics description}

\begin{tabular}{|c|c|c|c|c|c|}
\hline $\begin{array}{l}\text { How do these factors affect your wine } \\
\text { selection? }\end{array}$ & $\begin{array}{l}\text { Gender } \\
\text { group }\end{array}$ & $\mathbf{N}$ & Mean & $\begin{array}{c}\text { Std. } \\
\text { Deviation }\end{array}$ & $\begin{array}{l}\text { Std. Error } \\
\text { Mean }\end{array}$ \\
\hline \multirow[t]{2}{*}{ Colour of wine } & Male & 175 & 2.760 & 1.2409 & .0938 \\
\hline & Female & 396 & 2.439 & 1.1557 & .0581 \\
\hline \multirow[t]{2}{*}{ Label design (traditional, modern) } & Male & 175 & 3.349 & 1.0979 & .0830 \\
\hline & Female & 396 & 3.023 & 1.0467 & .0526 \\
\hline \multirow{2}{*}{$\begin{array}{l}\text { The information on a label (e.g. brand, } \\
\text { variety, quality class, country of origin, etc.) }\end{array}$} & Male & 175 & 2.406 & 1.0939 & .0827 \\
\hline & Female & 396 & 2.020 & .9303 & .0467 \\
\hline \multirow[t]{2}{*}{ Bottle shape } & Male & 175 & 3.760 & 1.1088 & .0838 \\
\hline & Female & 396 & 3.745 & 1.0400 & .0523 \\
\hline \multirow[t]{2}{*}{ Bottle colour } & Male & 175 & 3.903 & 1.0209 & .0772 \\
\hline & Female & 396 & 4.018 & .9013 & .0453 \\
\hline \multirow{2}{*}{$\begin{array}{l}\text { Type of bottle cap (e.g. cork plug, screw } \\
\text { cap) }\end{array}$} & Male & 175 & 3.434 & 1.1866 & .0897 \\
\hline & Female & 396 & 3.242 & 1.1829 & .0594 \\
\hline \multirow{2}{*}{$\begin{array}{l}\text { Medals (awards from wine competitions, } \\
\text { exhibitions) }\end{array}$} & Male & 175 & 3.331 & 1.1616 & .0878 \\
\hline & Female & 396 & 3.038 & 1.1826 & .0594 \\
\hline \multirow[t]{2}{*}{ Advertising } & Male & 175 & 3.960 & .9963 & .0753 \\
\hline & Female & 396 & 3.846 & .9327 & .0469 \\
\hline \multirow[t]{2}{*}{ Price } & Male & 175 & 2.743 & 1.0759 & .0813 \\
\hline & Female & 396 & 2.366 & .9439 & .0474 \\
\hline \multirow[t]{2}{*}{ Previous purchase experience } & Male & 175 & 1.869 & .9284 & .0702 \\
\hline & Female & 396 & 1.528 & .6726 & .0338 \\
\hline \multirow[t]{2}{*}{ Discounts } & Male & 175 & 3.331 & 1.1909 & .0900 \\
\hline & Female & 396 & 2.843 & 1.1050 & .0555 \\
\hline \multirow{2}{*}{$\begin{array}{l}\text { References from family, friends } \\
\text { and acquaintances }\end{array}$} & Male & 175 & 2.006 & .9855 & .0745 \\
\hline & Female & 396 & 1.821 & .7928 & .0398 \\
\hline \multirow{2}{*}{$\begin{array}{l}\text { Recommendations of the wine shop } \\
\text { operator, sommelier }\end{array}$} & Male & 175 & 2.686 & 1.1737 & .0887 \\
\hline & Female & 396 & 2.240 & 1.0934 & .0549 \\
\hline \multirow[t]{2}{*}{ Store availability } & Male & 175 & 3.291 & 1.1400 & .0862 \\
\hline & Female & 396 & 2.780 & 1.0601 & .0533 \\
\hline
\end{tabular}

Source: own research

\subsection{Are there any Differences in the Key Factors Influencing the Wine Choice between Men and Women of Generation Y?}

According to the Two-sample t-Test for equal means, and since the $\mathrm{P}$-values are greater than the significance level (0.05), we can state that we must reject the null hypothesis for these factors: bottle shape, bottle colour, type of bottle cap (e.g. cork plug, screw cap) and advertising. There are no differences in the perception of these key factors between men and women. According to respondents participating in the sample, we can confirm the differences between men's and women's perception of these key factors influencing the wine selection for males and females: colour of wine, label design (traditional, modern), the information 


\begin{tabular}{|c|c|c|c|c|c|c|c|c|c|}
\hline \multirow{3}{*}{ Factor } & \multicolumn{2}{|c|}{$\begin{array}{l}\text { Levene's test } \\
\text { for equality of } \\
\text { variances }\end{array}$} & \multicolumn{7}{|c|}{ T-test for equality of means } \\
\hline & \multirow[t]{2}{*}{$\mathbf{F}$} & \multirow[t]{2}{*}{ Sig. } & \multirow[t]{2}{*}{$\mathrm{t}$} & \multirow[t]{2}{*}{ df } & \multirow[t]{2}{*}{$\begin{array}{c}\text { Sig. } \\
\text { (2-tailed) }\end{array}$} & \multirow[t]{2}{*}{$\begin{array}{c}\text { Mean } \\
\text { difference }\end{array}$} & \multirow[t]{2}{*}{$\begin{array}{l}\text { Std. error } \\
\text { difference }\end{array}$} & \multicolumn{2}{|c|}{$\begin{array}{c}95 \% \text { confidence } \\
\text { interval } \\
\text { of the difference }\end{array}$} \\
\hline & & & & & & & & Lower & Upper \\
\hline Colour of wine & 1.144 & .285 & 2.987 & 569 & .003 & .3206 & .1073 & .1098 & .5314 \\
\hline Label design (traditional, modern) & & & 3.316 & 319 & .001 & .3258 & .0983 & .1325 & .5192 \\
\hline $\begin{array}{l}\text { The information on a label } \\
\text { (e.g. brand, variety, quality class, } \\
\text { country of origin, etc.) }\end{array}$ & & & 4.059 & 289 & .000 & .3855 & .0950 & .1986 & .5725 \\
\hline Bottle shape & .825 & .364 & .156 & 569 & .876 & .0151 & .0964 & -0.1742 & .2043 \\
\hline Bottle colour & 2.588 & .108 & -1.346 & 569 & .179 & -0.1148 & .0853 & -0.2823 & .0527 \\
\hline $\begin{array}{l}\text { Type of bottle cap (e.g. cork plug, } \\
\text { screw cap) }\end{array}$ & .242 & .623 & 1.785 & 569 & .075 & .1919 & .1075 & -0.0192 & .4030 \\
\hline $\begin{array}{l}\text { Medals (awards from wine } \\
\text { competitions, exhibitions) }\end{array}$ & .489 & .485 & 2.749 & 569 & .006 & .2935 & .1068 & .0838 & .5033 \\
\hline Advertising & .001 & .982 & 1.319 & 569 & .188 & .1140 & .0865 & -0.0558 & .2839 \\
\hline Price & 3.191 & .075 & 4.208 & 569 & .000 & .3767 & .0895 & .2009 & .5525 \\
\hline Previous purchase experience & & & 4.375 & 257 & .000 & .3408 & .0779 & .1874 & .4942 \\
\hline Discounts & 3.786 & .052 & 4.749 & 569 & .000 & .4880 & .1027 & .2862 & .6898 \\
\hline $\begin{array}{l}\text { References from family, friends } \\
\text { and acquaintances }\end{array}$ & & & 2.190 & 277 & .029 & .1850 & .0845 & .2405 & .6512 \\
\hline $\begin{array}{l}\text { Recommendations of the wine } \\
\text { shop operator, sommelier }\end{array}$ & 2.122 & .146 & 4.391 & 569 & .000 & .4458 & .1015 & .2464 & .6452 \\
\hline Store availability & 2.846 & .092 & 5.189 & 569 & .000 & .5111 & .0985 & .3177 & .7046 \\
\hline
\end{tabular}

on a label (e.g. brand, variety, quality class, country of origin, etc.), medals (awards from wine competitions, exhibitions), price, previous purchase experience, discounts, references from family, friends and acquaintances, recommendations of the wine shop operator, sommelier and store availability, as can be seen from Tab. 3.

\subsection{Are there any Differences in the Key Factors Influencing the Wine Choice of the Respondents according to their Income?}

For this part of the survey, respondents were divided into 9 groups.

Group 1 - income up to CZK 5,000 per month Group 2 - income CZK 5,001-10,000 per month Group 3 - income CZK 10,001-15,000 per month
Group 4 - income CZK 15,001-20,000 per month Group 5 - income CZK 20,001-30,000 per month Group 6 - income CZK 30,001-40,000 per month Group 7 - more than CZK 40,000 per month Group 8 - no income Group 9 - no answer

Based on the result of chi-square test, we can claim that there are no differences among the income group for these factors: colour of wine, label design, the information on a label, type of bottle cap, medals, advertising, price, previous purchase experience, discounts, references from family, friends and acquaintances and recommendations of the wine shop operator, sommelier, as can be seen from Tab. 5. On the other hand, according these results, there are no differences among the income group for three factors: bottle shape, bottle colour and store availability. 


\section{Tab. 4: Group statistics description (Part 1)}

\begin{tabular}{|c|c|c|c|c|c|c|c|c|c|}
\hline \multirow{2}{*}{\multicolumn{2}{|c|}{$\begin{array}{l}\text { How do these factors affect } \\
\text { your wine selection? }\end{array}$}} & \multirow{3}{*}{$\begin{array}{l}\mathbf{N} \\
159 \\
\end{array}$} & \multirow{3}{*}{$\begin{array}{l}\text { Mean } \\
2.390\end{array}$} & \multirow{3}{*}{$\begin{array}{c}\begin{array}{c}\text { Std. } \\
\text { deviation }\end{array} \\
1.1849\end{array}$} & \multirow{3}{*}{$\begin{array}{l}\text { Std. } \\
\text { error }\end{array}$} & \multicolumn{2}{|c|}{$\begin{array}{l}95 \% \text { confidence } \\
\text { interval for mean }\end{array}$} & \multirow{3}{*}{$\begin{array}{c}\text { Mini- } \\
\text { mum } \\
1.0\end{array}$} & \multirow{3}{*}{$\begin{array}{r}\begin{array}{r}\text { Maxi- } \\
\text { mum }\end{array} \\
5.0\end{array}$} \\
\hline & & & & & & \multirow{2}{*}{$\begin{array}{r}\begin{array}{r}\text { Lower } \\
\text { bound }\end{array} \\
2.204\end{array}$} & \multirow{2}{*}{$\begin{array}{c}\begin{array}{c}\text { Upper } \\
\text { bound }\end{array} \\
2.576\end{array}$} & & \\
\hline Colour of wine & 1 & & & & & & & & \\
\hline & 2 & 120 & 2.642 & 1.1653 & .1064 & 2.431 & 2.852 & 1.0 & 5.0 \\
\hline & 3 & 36 & 2.417 & 1.2507 & .2085 & 1.993 & 2.840 & 1.0 & 5.0 \\
\hline & 4 & 19 & 2.526 & 1.0733 & .2462 & 2.009 & 3.044 & 1.0 & 5.0 \\
\hline & 5 & 19 & 3.000 & 1.2019 & .2757 & 2.421 & 3.579 & 1.0 & 5.0 \\
\hline & 6 & 6 & 1.667 & 1.0328 & .4216 & .583 & 2.751 & 1.0 & 3.0 \\
\hline & 7 & 1 & 4.000 & . & . & . & & 4.0 & 4.0 \\
\hline & 8 & 183 & 2.617 & 1.2252 & .0906 & 2.439 & 2.796 & 1.0 & 5.0 \\
\hline & 9 & 28 & 2.393 & 0.9940 & .1879 & 2.007 & 2.778 & 1.0 & 4.0 \\
\hline & Total & 571 & 2.538 & 1.1906 & .0498 & 2.440 & 2.636 & 1.0 & 5.0 \\
\hline \multirow{10}{*}{$\begin{array}{l}\text { Label design (traditional, } \\
\text { modern) }\end{array}$} & 1 & 159 & 3.094 & 1.0602 & .0841 & 2.928 & 3.260 & 1.0 & 5.0 \\
\hline & 2 & 120 & 3.067 & 1.0590 & .0967 & 2.875 & 3.258 & 1.0 & 5.0 \\
\hline & 3 & 36 & 3.083 & 1.0790 & .1798 & 2.718 & 3.448 & 1.0 & 5.0 \\
\hline & 4 & 19 & 3.368 & 1.0651 & .2444 & 2.855 & 3.882 & 1.0 & 5.0 \\
\hline & 5 & 19 & 3.368 & 1.4225 & .3263 & 2.683 & 4.054 & 1.0 & 5.0 \\
\hline & 6 & 6 & 3.667 & 1.5055 & .6146 & 2.087 & 5.247 & 1.0 & 5.0 \\
\hline & 7 & 1 & 3.000 & . & . & . & & 3.0 & 3.0 \\
\hline & 8 & 183 & 3.077 & 1.0402 & .0769 & 2.925 & 3.228 & 1.0 & 5.0 \\
\hline & 9 & 28 & 3.429 & 1.0690 & .2020 & 3.014 & 3.843 & 1.0 & 5.0 \\
\hline & Total & 571 & 3.123 & 1.0723 & .0449 & 3.034 & 3.211 & 1.0 & 5.0 \\
\hline \multirow{10}{*}{$\begin{array}{l}\text { The information on a label } \\
\text { (e.g. brand, variety, quality } \\
\text { class, country of origin, } \\
\text { etc.) }\end{array}$} & 1 & 159 & 2.189 & 1.0444 & .0828 & 2.025 & 2.352 & 1.0 & 5.0 \\
\hline & 2 & 120 & 2.083 & 0.9401 & .0858 & 1.913 & 2.253 & 1.0 & 5.0 \\
\hline & 3 & 36 & 2.278 & 1.0032 & .1672 & 1.938 & 2.617 & 1.0 & 5.0 \\
\hline & 4 & 19 & 1.947 & 0.9113 & .2091 & 1.508 & 2.387 & 1.0 & 4.0 \\
\hline & 5 & 19 & 1.632 & 0.7609 & .1746 & 1.265 & 1.998 & 1.0 & 3.0 \\
\hline & 6 & 6 & 3.000 & 1.5492 & .6325 & 1.374 & 4.626 & 1.0 & 5.0 \\
\hline & 7 & 1 & 3.000 & . & . & . & . & 3.0 & 3.0 \\
\hline & 8 & 183 & 2.208 & 0.9948 & .0735 & 2.063 & 2.353 & 1.0 & 5.0 \\
\hline & 9 & 28 & 1.714 & 0.8545 & .1615 & 1.383 & 2.046 & 1.0 & 4.0 \\
\hline & Total & 571 & 2.138 & 0.9983 & .0418 & 2.056 & 2.220 & 1.0 & 5.0 \\
\hline
\end{tabular}




\section{Tab. 4: Group statistics description (Part 2)}

\begin{tabular}{|c|c|c|c|c|c|c|c|c|c|}
\hline \multirow[t]{10}{*}{ Bottle shape } & 1 & 159 & 3.635 & 1.1331 & .0899 & 3.458 & 3.813 & 1.0 & 5.0 \\
\hline & 2 & 120 & 3.900 & .9562 & .0873 & 3.727 & 4.073 & 2.0 & 5.0 \\
\hline & 3 & 36 & 3.667 & .9562 & .1594 & 3.343 & 3.990 & 2.0 & 5.0 \\
\hline & 4 & 19 & 3.579 & .9612 & .2205 & 3.116 & 4.042 & 2.0 & 5.0 \\
\hline & 5 & 19 & 3.632 & 1.4985 & .3438 & 2.909 & 4.354 & 1.0 & 5.0 \\
\hline & 6 & 6 & 3.000 & 1.6733 & .6831 & 1.244 & 4.756 & 1.0 & 5.0 \\
\hline & 7 & 1 & 3.000 & . & . & . & . & 3.0 & 3.0 \\
\hline & 8 & 183 & 3.803 & 1.0080 & .0745 & 3.656 & 3.950 & 1.0 & 5.0 \\
\hline & 9 & 28 & 3.893 & 1.0659 & .2014 & 3.480 & 4.306 & 2.0 & 5.0 \\
\hline & Total & 571 & 3.750 & 1.0606 & .0444 & 3.662 & 3.837 & 1.0 & 5.0 \\
\hline \multirow[t]{10}{*}{ Bottle colour } & 1 & 159 & 3.887 & .9999 & .0793 & 3.730 & 4.043 & 1.0 & 5.0 \\
\hline & 2 & 120 & 4.058 & .9102 & .0831 & 3.894 & 4.223 & 2.0 & 5.0 \\
\hline & 3 & 36 & 3.972 & .7741 & .1290 & 3.710 & 4.234 & 2.0 & 5.0 \\
\hline & 4 & 19 & 3.895 & 1.0485 & .2405 & 3.389 & 4.400 & 2.0 & 5.0 \\
\hline & 5 & 19 & 4.000 & 1.2910 & .2962 & 3.378 & 4.622 & 1.0 & 5.0 \\
\hline & 6 & 6 & 3.333 & 1.8619 & .7601 & 1.379 & 5.287 & 1.0 & 5.0 \\
\hline & 7 & 1 & 3.000 & . & . & . & . & 3.0 & 3.0 \\
\hline & 8 & 183 & 4.022 & .8578 & .0634 & 3.897 & 4.147 & 1.0 & 5.0 \\
\hline & 9 & 28 & 4.179 & .8189 & .1548 & 3.861 & 4.496 & 3.0 & 5.0 \\
\hline & Total & 571 & 3.982 & .9402 & .0393 & 3.905 & 4.060 & 1.0 & 5.0 \\
\hline \multirow{10}{*}{$\begin{array}{l}\text { Type of bottle cap (e.g. } \\
\text { cork plug, screw cap) }\end{array}$} & 1 & 159 & 3.170 & 1.2024 & .0954 & 2.981 & 3.358 & 1.0 & 5.0 \\
\hline & 2 & 120 & 3.292 & 1.1552 & .1055 & 3.083 & 3.500 & 1.0 & 5.0 \\
\hline & 3 & 36 & 3.472 & 1.2758 & .2126 & 3.041 & 3.904 & 1.0 & 5.0 \\
\hline & 4 & 19 & 3.421 & 1.1213 & .2572 & 2.881 & 3.962 & 1.0 & 5.0 \\
\hline & 5 & 19 & 3.579 & 1.3871 & .3182 & 2.910 & 4.247 & 1.0 & 5.0 \\
\hline & 6 & 6 & 2.833 & 1.1690 & .4773 & 1.606 & 4.060 & 1.0 & 4.0 \\
\hline & 7 & 1 & 3.000 & . & . & . & . & 3.0 & 3.0 \\
\hline & 8 & 183 & 3.355 & 1.1481 & .0849 & 3.188 & 3.523 & 1.0 & 5.0 \\
\hline & 9 & 28 & 3.357 & 1.3113 & .2478 & 2.849 & 3.866 & 1.0 & 5.0 \\
\hline & Total & 571 & 3.301 & 1.1863 & .0496 & 3.204 & 3.399 & 1.0 & 5.0 \\
\hline \multirow{10}{*}{$\begin{array}{l}\text { Medals (awards from wine } \\
\text { competitions, exhibitions) }\end{array}$} & 1 & 159 & 3.208 & 1.1911 & .0945 & 3.021 & 3.394 & 1.0 & 5.0 \\
\hline & 2 & 120 & 3.075 & 1.1751 & .1073 & 2.863 & 3.287 & 1.0 & 5.0 \\
\hline & 3 & 36 & 2.778 & 1.1241 & .1873 & 2.397 & 3.158 & 1.0 & 5.0 \\
\hline & 4 & 19 & 3.263 & 1.1471 & .2632 & 2.710 & 3.816 & 1.0 & 5.0 \\
\hline & 5 & 19 & 3.053 & 1.1773 & .2701 & 2.485 & 3.620 & 1.0 & 5.0 \\
\hline & 6 & 6 & 3.833 & 1.6021 & .6540 & 2.152 & 5.515 & 1.0 & 5.0 \\
\hline & 7 & 1 & 2.000 & & . & & . & 2.0 & 2.0 \\
\hline & 8 & 183 & 3.164 & 1.1885 & .0879 & 2.991 & 3.337 & 1.0 & 5.0 \\
\hline & 9 & 28 & 2.964 & 1.1380 & .2151 & 2.523 & 3.406 & 1.0 & 5.0 \\
\hline & Total & 571 & 3.128 & 1.1830 & .0495 & 3.031 & 3.225 & 1.0 & 5.0 \\
\hline
\end{tabular}




\section{Tab. 4: Group statistics description (Part 3)}

\begin{tabular}{|c|c|c|c|c|c|c|c|c|c|}
\hline \multirow[t]{10}{*}{ Advertising } & 1 & 159 & 3.836 & .9800 & .0777 & 3.683 & 3.990 & 1.0 & 5.0 \\
\hline & 2 & 120 & 3.892 & 1.0191 & .0930 & 3.707 & 4.076 & 1.0 & 5.0 \\
\hline & 3 & 36 & 3.944 & .9241 & .1540 & 3.632 & 4.257 & 2.0 & 5.0 \\
\hline & 4 & 19 & 3.789 & .8550 & .1961 & 3.377 & 4.202 & 3.0 & 5.0 \\
\hline & 5 & 19 & 4.158 & 1.0145 & .2327 & 3.669 & 4.647 & 1.0 & 5.0 \\
\hline & 6 & 6 & 4.167 & .9832 & .4014 & 3.135 & 5.198 & 3.0 & 5.0 \\
\hline & 7 & 1 & 3.000 & . & . & . & . & 3.0 & 3.0 \\
\hline & 8 & 183 & 3.863 & .9066 & .0670 & 3.731 & 3.996 & 1.0 & 5.0 \\
\hline & 9 & 28 & 3.964 & .9222 & .1743 & 3.607 & 4.322 & 2.0 & 5.0 \\
\hline & Total & 571 & 3.881 & .9532 & .0399 & 3.803 & 3.959 & 1.0 & 5.0 \\
\hline \multirow[t]{10}{*}{ Price } & 1 & 159 & 2.283 & .9555 & .0758 & 2.133 & 2.433 & 1.0 & 5.0 \\
\hline & 2 & 120 & 2.508 & 1.0042 & .0917 & 2.327 & 2.690 & 1.0 & 5.0 \\
\hline & 3 & 36 & 2.806 & 1.0091 & .1682 & 2.464 & 3.147 & 1.0 & 5.0 \\
\hline & 4 & 19 & 2.842 & .8342 & .1914 & 2.440 & 3.244 & 2.0 & 5.0 \\
\hline & 5 & 19 & 2.737 & .8719 & .2000 & 2.317 & 3.157 & 1.0 & 4.0 \\
\hline & 6 & 6 & 2.833 & 1.1690 & .4773 & 1.606 & 4.060 & 1.0 & 4.0 \\
\hline & 7 & 1 & 4.000 & . & . & . & . & 4.0 & 4.0 \\
\hline & 8 & 183 & 2.475 & 1.0208 & .0755 & 2.327 & 2.624 & 1.0 & 5.0 \\
\hline & 9 & 28 & 2.571 & 1.0690 & .2020 & 2.157 & 2.986 & 1.0 & 5.0 \\
\hline & Total & 571 & 2.482 & 1.0005 & .0419 & 2.399 & 2.564 & 1.0 & 5.0 \\
\hline \multirow{10}{*}{$\begin{array}{l}\text { Previous purchase } \\
\text { experience }\end{array}$} & 1 & 159 & 1.579 & .8065 & .0640 & 1.452 & 1.705 & 1.0 & 5.0 \\
\hline & 2 & 120 & 1.633 & .7985 & .0729 & 1.489 & 1.778 & 1.0 & 5.0 \\
\hline & 3 & 36 & 1.833 & .8106 & .1351 & 1.559 & 2.108 & 1.0 & 4.0 \\
\hline & 4 & 19 & 1.632 & .6840 & .1569 & 1.302 & 1.961 & 1.0 & 3.0 \\
\hline & 5 & 19 & 1.737 & .7335 & .1683 & 1.383 & 2.090 & 1.0 & 3.0 \\
\hline & 6 & 6 & 1.667 & .8165 & .3333 & .810 & 2.524 & 1.0 & 3.0 \\
\hline & 7 & 1 & 2.000 & . & . & . & . & 2.0 & 2.0 \\
\hline & 8 & 183 & 1.628 & .7513 & .0555 & 1.519 & 1.738 & 1.0 & 5.0 \\
\hline & 9 & 28 & 1.607 & .7373 & .1393 & 1.321 & 1.893 & 1.0 & 3.0 \\
\hline & Total & 571 & 1.632 & .7755 & .0325 & 1.568 & 1.696 & 1.0 & 5.0 \\
\hline \multirow[t]{10}{*}{ Discounts } & 1 & 159 & 2.767 & 1.0744 & .0852 & 2.599 & 2.936 & 1.0 & 5.0 \\
\hline & 2 & 120 & 3.000 & 1.1302 & .1032 & 2.796 & 3.204 & 1.0 & 5.0 \\
\hline & 3 & 36 & 3.222 & 1.1979 & .1996 & 2.817 & 3.628 & 1.0 & 5.0 \\
\hline & 4 & 19 & 3.211 & 1.1822 & .2712 & 2.641 & 3.780 & 1.0 & 5.0 \\
\hline & 5 & 19 & 3.316 & 1.3355 & .3064 & 2.672 & 3.959 & 1.0 & 5.0 \\
\hline & 6 & 6 & 3.167 & 1.4720 & .6009 & 1.622 & 4.711 & 1.0 & 5.0 \\
\hline & 7 & 1 & 4.000 & . & . & . & . & 4.0 & 4.0 \\
\hline & 8 & 183 & 3.000 & 1.1626 & .0859 & 2.830 & 3.170 & 1.0 & 5.0 \\
\hline & 9 & 28 & 3.464 & 1.2013 & .2270 & 2.998 & 3.930 & 1.0 & 5.0 \\
\hline & Total & 571 & 2.993 & 1.1532 & .0483 & 2.898 & 3.088 & 1.0 & 5.0 \\
\hline
\end{tabular}




\section{Tab. 4: Group statistics description (Part 4)}

\begin{tabular}{|c|c|c|c|c|c|c|c|c|c|}
\hline \multirow{10}{*}{$\begin{array}{l}\text { References from family, } \\
\text { friends and acquaintances }\end{array}$} & 1 & 159 & 1.799 & .8914 & .0707 & 1.659 & 1.938 & 1.0 & 5.0 \\
\hline & 2 & 120 & 1.867 & .8593 & .0784 & 1.711 & 2.022 & 1.0 & 5.0 \\
\hline & 3 & 36 & 1.972 & .7741 & .1290 & 1.710 & 2.234 & 1.0 & 4.0 \\
\hline & 4 & 19 & 2.158 & .7647 & .1754 & 1.789 & 2.526 & 1.0 & 4.0 \\
\hline & 5 & 19 & 1.895 & .9366 & .2149 & 1.443 & 2.346 & 1.0 & 4.0 \\
\hline & 6 & 6 & 2.833 & 1.3292 & .5426 & 1.438 & 4.228 & 1.0 & 5.0 \\
\hline & 7 & 1 & 1.000 & . & . & 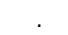 & . & 1.0 & 1.0 \\
\hline & 8 & 183 & 1.885 & .8274 & .0612 & 1.765 & 2.006 & 1.0 & 5.0 \\
\hline & 9 & 28 & 1.821 & .8189 & .1548 & 1.504 & 2.139 & 1.0 & 4.0 \\
\hline & Total & 571 & 1.877 & .8598 & .0360 & 1.807 & 1.948 & 1.0 & 5.0 \\
\hline \multirow{10}{*}{$\begin{array}{l}\text { Recommendations of } \\
\text { the wine shop operator, } \\
\text { sommelier }\end{array}$} & 1 & 159 & 2.258 & 1.1093 & .0880 & 2.084 & 2.432 & 1.0 & 5.0 \\
\hline & 2 & 120 & 2.283 & 1.1389 & .1040 & 2.077 & 2.489 & 1.0 & 5.0 \\
\hline & 3 & 36 & 2.417 & 1.1802 & 1967 & 2.017 & 2.816 & 1.0 & 5.0 \\
\hline & 4 & 19 & 2.684 & 1.1082 & .2542 & 2.150 & 3.218 & 1.0 & 5.0 \\
\hline & 5 & 19 & 2.737 & 1.3680 & .3138 & 2.078 & 3.396 & 1.0 & 5.0 \\
\hline & 6 & 6 & 3.000 & 1.2649 & .5164 & 1.673 & 4.327 & 2.0 & 5.0 \\
\hline & 7 & 1 & 2.000 & . & . & . & . & 2.0 & 2.0 \\
\hline & 8 & 183 & 2.437 & 1.1603 & .0858 & 2.268 & 2.606 & 1.0 & 5.0 \\
\hline & 9 & 28 & 2.429 & .8357 & .1579 & 2.105 & 2.753 & 1.0 & 4.0 \\
\hline & Total & 571 & 2.377 & 1.1364 & .0476 & 2.283 & 2.470 & 1.0 & 5.0 \\
\hline \multirow[t]{10}{*}{ Store availability } & 1 & 159 & 2.704 & 1.0998 & .0872 & 2.532 & 2.877 & 1.0 & 5.0 \\
\hline & 2 & 120 & 2.875 & 1.0890 & .0994 & 2.678 & 3.072 & 1.0 & 5.0 \\
\hline & 3 & 36 & 3.194 & .9804 & .1634 & 2.863 & 3.526 & 1.0 & 5.0 \\
\hline & 4 & 19 & 3.211 & .9763 & .2240 & 2.740 & 3.681 & 2.0 & 5.0 \\
\hline & 5 & 19 & 3.368 & 1.4985 & .3438 & 2.646 & 4.091 & 1.0 & 5.0 \\
\hline & 6 & 6 & 3.833 & .9832 & .4014 & 2.802 & 4.865 & 3.0 & 5.0 \\
\hline & 7 & 1 & 3.000 & . & . & . & . & 3.0 & 3.0 \\
\hline & 8 & 183 & 2.973 & 1.0865 & .0803 & 2.814 & 3.131 & 1.0 & 5.0 \\
\hline & 9 & 28 & 3.286 & 1.1174 & .2112 & 2.852 & 3.719 & 1.0 & 5.0 \\
\hline & Total & 571 & 2.937 & 1.1096 & .0464 & 2.846 & 3.028 & 1.0 & 5.0 \\
\hline
\end{tabular}

\section{Discussion}

Based on the above research results, findings have been identified, which will be compared here with similar surveys conducted in other countries. Young respondents in the Czech Republic prefer white wines to red and rosé. The most popular white varieties are Chardonnay, Palava, Traminer Rot, Pinot Gris and Sauvignon. Popular red varieties include Blauer Portugieser, Cabernet Sauvignon,
Merlot and Pinot Noir. Fountain and Lamb (2011) also found in New Zealand's research that Generation $Y$ respondents choose more frequently white wine $(56.6 \%)$ than red $(13.2 \%)$ or rosé wine $(7.5 \%)$ for an everyday drinking occasion. Regarding to wine varieties, in contrast to the results of Czech respondents, the most popular white variety was Sauvignon $(40 \%)$. On the contrary, the less popular variety was Chardonnay (15.6\%). In relation to red 


\begin{tabular}{l|c|c|c}
\multicolumn{1}{c|}{ Factor } & Value & df & Asymp. Sig. \\
\hline Colour of wine & 35.695 & 32 & .299 \\
\hline Label design (traditional, modern) & 31.306 & 32 & .501 \\
\hline $\begin{array}{l}\text { The information on a label (e.g. brand, variety, quality class, } \\
\text { country of origin, etc.) }\end{array}$ & 40.588 & 32 & .501 \\
\hline Bottle shape & 54.828 & 32 & .007 \\
\hline Bottle colour & 67.861 & 32 & .000 \\
\hline Type of bottle cap (e.g. cork plug, screw cap) & 27.960 & 32 & .671 \\
\hline Medals (awards from wine competitions, exhibitions) & 34.586 & 32 & .345 \\
\hline Advertising & 34.430 & 32 & .352 \\
\hline Price & 36.677 & 32 & .261 \\
\hline Previous purchase experience & 20.584 & 32 & .940 \\
\hline Discounts & 43.985 & 32 & .077 \\
\hline References from family, friends and acquaintances & 37.728 & 32 & .224 \\
\hline Recommendations of the wine shop operator, sommelier & 32.620 & 32 & .436 \\
\hline Store availability & 46.496 & 32 & .047 \\
\hline
\end{tabular}

varieties, $15.6 \%$ of respondents - almost the same number as in the Czech Republic purchased Pinot Noir, but no New Zealand respondent of Generation $Y$ marked Cabernet Sauvignon. On the other hand, young people of Generation Y aged 18-25 in the Republic of Moldova prefer red wines. Among popular red wine varieties belonged Cahors and Cabernet Sauvignon. Less popular were then white wine varieties, such as Aligote and Sauvignon, as stated in the research of Stanciu and Neagu (2014). This difference may be due to the fact that most Moldovan consumers prefer local wines made in the Republic of Moldova over imported ones. Generation $Y$ in the USA prefers red wines, closely followed by white wines. The most popular varieties, as in the Czech Republic, are red varieties Cabernet Sauvignon and Merlot, white varieties are then Chardonnay, Sauvignon and Pinot Gris. (Olsen et al., 2007). Most respondents (60\%) have a general knowledge of wine in the Czech Republic, $25 \%$ have wine minimal awareness, $13 \%$ have a deeper knowledge of wine and only $2 \%$ of the respondents think that their wine awareness is none. On the contrary, the survey sample in Australia and New Zealand was most constituted by respondents with basic knowledge of wine $(56.7 \%)$, then intermediate knowledge (21.2\%), no knowledge (17.1\%) and only $4.9 \%$ of respondents had advanced knowledge of wine (Treloar et al., 2004). Based on this information, it can thus be concluded that young people from the Czech Republic generally have better wine awareness, they understand better wines and have a closer relationship to wine. However, it is necessary to further deepen this knowledge, in particular among consumers who have minimal or no knowledge of wine.

Preferred places of purchase are wine shops and supermarkets, the least preferred are e-shops. Stanciu and Neagu (2014) found similar results, namely that young Moldovan consumers aged 18-25 buy wine most often in supermarkets, then the neighbourhood shops and specialized wine shops. Also, American Generation $Y$ most often buys wine in stores (liquor, grocery) and wine shops, at least on the Internet (Chrysochou et al., 2012). Czech young consumers buy wine for the purpose of meeting with friends, sitting at home when they drink wine during meals, and celebrations. These same findings were found in the research of Olsen et al. (2007), where respondents answered that they most often consume wine with meals, to relax and at formal celebrations. Also, research by authors Stanciu and Neagu 
(2014) confirms that most young people aged 18-25 prefer to drink wine at home (52\%) and with friends (38\%). Only $10 \%$ of respondents rather consume wine at restaurants. This also coincides with the results of survey conducted in Verona in Italy, where Agnoli et al. (2011) state that if consumers drink alcohol at home, they often prefer wine to other types of alcohol. It is probably a traditional habit, for example, when costumers consume wine while eating or open a bottle of wine with their friends.

The most important factors influencing wine selection of Generation $Y$ are previous purchase experience and references from family, friends and acquaintances. Furthermore, the information on a label, recommendations of the wine shop operator or sommelier, price and colour of wine. On the other hand, less important factors, relevant for young consumers of wine, are bottle shape, bottle colour and advertising. Compared with other studies of foreign authors, the most important attribute influencing consumers of Generation $Y$ in the USA and South Africa is tasted the wine previously (de Magistris et al., 2011; Chrysochou et al., 2012; Lategan et al., 2017), which is the same as our first the most important attribute called previous purchase experience. This finding shows that consumers place significant emphasis on previous experiences, whether direct, personal or sensorial (Chrysochou et al., 2012). The order of other important factors varies slightly across individual scientific studies, but they include recommendations from someone, price, variety and brand (in our case, the information on a label). However, de Magistris et al. (2011) mark the brand as one of the least important factors. In their research, they also list attributes that influence Spanish respondents. These results differ from previous studies. The most important factors here are designation of origin, matching food and country of origin.

\section{Conclusions}

The aim of this study was to describe the purchasing preferences of young consumers and identify the factors influencing the purchasing decisions of Generation $Y$ consumers in the wine selection process in the Czech Republic. The research was composed in particular from young people of high school degree, who have continued their studies and are still students. Most of these students do not work and thus do not receive any salary or they work as temporary workers and their monthly income is up to CZK 5,000. There are a lot of factors affecting the wine selection process which have been identified previously. In this study, 14 attributes were outlined and their effect on consumers aged 18-25 in the selection of wine was examined. Many authors include also 'taste' among these factors. However, in our survey, this attribute was not included among the examined factors, because the essence of the research was to find out how consumers are choosing wine through the visual presentation of wine on the shelf. The factor 'taste' is therefore notionally part of the attribute 'previous purchase experience'. Previous purchase experience (this can also include the question of the taste of wine, namely whether the customer liked or did not like the wine), and references from family, friends and acquaintances most influence the Czech consumers when buying wine. So young people prefer their own experience and advice from their loved ones to bottle shape, bottle colour, or advertising that are the least important factors.

The survey has shown that Generation $Y$ is an attractive wine segment that represents the future of this market and therefore more attention needs to be focused on it. The study's conclusions suggest that Generation $Y$ consumers in the Czech Republic and other countries have similar but also different preferences in wine selection, whether it is colour of wine, varieties or other factors that influence their purchasing decisions. From the above findings it can be stated that young people of Generation $Y$ are not a homogeneous group. It is therefore necessary to recognise the individuality of this young segment and to focus in more detail on the research of its consumer preferences.

One of the limitations of this article is the fact that the survey was focused on the closer part of Generation Y, i.e. on young people aged 1825. The recommendation for further research is to extend the target group by acquiring other respondents of other age categories belonging to Generation Y. The literature regarding Generation $Y$ and buying behaviour in wine selection is relatively insufficient in the Czech Republic. Therefore, for further research, it will be a good idea to explore more of this area and to focus on, for example, the comparison of individual generational cohorts among 
themselves. Another limit may be the fact that the article focuses only on more general factors that affect consumers when choosing wine. For a deeper understanding of the examined issue, it would be appropriate for further studies to subdivide the attribute 'the information on a label' into the following factors: brand/ producer, variety, vintage year, quality class of wine, country of origin, wine-growing region, residual sugar content, actual alcoholic strength, nominal volume and recommendations on a combination of wine with appropriate meals. A more complete examination of these factors may provide more specific information on consumer decision-making, which will also be useful in practice, for example, in drawing up marketing strategies.

This paper was written with support from the Internal Grant Agency of FaME TBU No. IGA/FaME/2016/009 'The Use of New Marketing Trends for Increasing of Companies' Performance in Selected Areas of Economy.

\section{References}

Agnoli, L., Begalli, D., \& Capitello, R. (2011). Generation Y's perception of wine and consumption situations in a traditional wineproducing region. International Journal of Wine Business Research, 23(2), 176-192. http://doi. org/10.1108/17511061111143025.

Anchor, J. R., \& Lacinová, T. (2015). Czech wine consumers: maturing with age? E\&M Ekonomie a Management, 18(1), 169-182. http://doi.org/10.15240/tul/001/2015-1-013.

Atkin, T., Nowak, L., \& Garcia, R. (2007). Women wine consumers: information search and retailing implications. International Journal of Wine Business Research, 19(4), 327-339. http://doi.org/10.1108/17511060710837454.

Bárta, L. (2013). Public relations a marketingová komunikace $v$ obchodu $s$ vínem. Praha: Radix.

Bejtkovský, J. (2016). The Employees of Baby Boomers Generation, Generation X, Generation $Y$ and Generation $Z$ in Selected Czech Corporations as Conceivers of Development and Competitiveness in their Corporation. Journal of Competitiveness, 8(4), 105-123. http://doi.org/10.7441/joc.2016.04.07.

Bencsik, A., Juhász, T., \& Horváth-Csikós, G. (2016). Y and Z Generations at Workplaces. Journal of Competitiveness, 6(3), 90-106. http://doi.org/10.7441/joc.2016.03.06.
Bruwer, J., Saliba, A., \& Miller, B. (2011). Consumer behaviour and sensory preference differences: implications for wine product marketing. Journal of Consumer Marketing, 28(1), 5-18. http://doi.org/10.1108/07363761111101903.

Charters, S., Velikova, N., Ritchie, C., Fountain, J., Thach, L., Dodd, T. H., Fish, N., Herbst, F., \& Terblanche, N. (2011). Generation $Y$ and sparkling wines. International Journal of Wine Business Research, 23(2), 161-175. http://doi.org/10.1108/17511061111143016.

Chládková, H. (2015). Consumer behaviour on the Czech wine market. Acta Universitatis Agriculturae et Silviculturae Mendelianae Brunensis, 52(6), 175-188. http://doi. org/10.11118/actaun200452060175.

Chrysochou, P., Krystallis, A., Mocanu, A., \& Lewis, R. L. (2012). Generation Y preferences for wine. British Food Journal, 114(4), 516-528. http://doi.org/10.1108/00070701211219531.

de Magistris, T., Groot, E., Gracia, A., \& Albisu, L. M. (2011). Do Millennial generation's wine preferences of the "New World" differ from the "Old World"?: A pilot study. International Journal of Wine Business Research, 23(2), 145-160. http://doi. org/10.1108/17511061111143007.

Doyle, C. (2011). A dictionary of marketing. Oxford: Oxford University Press.

Fountain, J., \& Lamb, C. (2011). Generation $Y$ as young wine consumers in New Zealand: how do they differ from Generation X? International Journal of Wine Business Research, 23(2), 107-124. http://doi. org/10.1108/17511061111142981.

Gunay, G. N., \& Baker, M. J. (2011). The factors influencing consumers' behaviour on wine consumption in the Turkish wine market. EuroMed Journal of Business, 6(3), 324-341. http://doi.org/10.1108/14502191111170150.

Horváthová, P., Bláha, J., \& Čopíková, A. (2016). Řizení lidských zdrojů: nové trendy. Praha: Management Press.

Klapilová Krbová, P. (2016). Generation Y Attitudes towards Shopping: A Comparison of the Czech Republic and Slovakia. Journal of Competitiveness, 8(1), 38-54. http://doi. org/10.7441/joc.2016.01.03.

Kotler, P., \& Armstrong, G. (2016). Principles of Marketing, 16th Edition. Harlow: Pearson Education Limited.

Kotler, P., \& Keller, K. L. (2016). Marketing management, 15th Edition. Harlow: Pearson Education Limited. 
Lake, L. (2009). Consumer Behavior For Dummies. Hoboken, NJ: Wiley Publishing, Inc.

Lategan, B. W., Pentz, C. D., \& Preez, R. D. (2017). Importance of wine attributes: a South African Generation $Y$ perspective. British Food Journal, 119(7), 1536-1546. http://doi. org/10.1108/bfj-09-2016-0420.

Noble, S. M., Haytko, D. L., \& Phillips, J. (2009). What drives college-age Generation Y consumers? Journal of Business Research, 62(6), 617-628. http://doi.org/10.1016/j. jbusres.2008.01.020.

Olsen, J. E., Thach, L., \& Nowak, L. (2007). Wine for My Generation: Exploring How US Wine Consumers are Socialized to Wine. Journal of Wine Research, 18(1), 1-18. http://doi.org/10.1080/09571260701526816.

Schiffman, L., O'Cass, A., Paladino, A., \& Carlson, J. (2014). Consumer Behaviour. Frenchs Forest NSW: Pearson Australia.

Schiffman, L. G., \& Wisenblit, J. (2015). Consumer Behavior. Harlow: Pearson Education Limited.

Schiffman, L. G., Kanuk, L. L., \& Hansen, H. (2012). Consumer Behaviour: A European Outlook. Harlow: Pearson Education Limited.

Schwartz, J., Hole, D., \& Zhong, L. (2010). Talking about Whose Generation? Why Western generational models can't account for a global workforce. Deloitte University Press. Retrieved June 27, 2018, from https://www2.deloitte.com/ insights/us/en/deloitte-review/issue-6/talkingabout-whose-generation-ages-and-attitudesamong-the-global-workforce.html.

Solomon, M. R., Bamossy, G., Askegaard, S., \& Hogg, M. K. (2010). Consumer Behaviour: A European Perspective. Harlow: Prentice Hall/ Financial Times.

Stanciu, S., \& Neagu, T. (2014). The Factors Influencing Consumers' Behaviour on Wine
Consumption in the Moldovan Wine Market. Risk in Contemporary Economy, 1(1), 406-418.

Straková, A. (2017). Výroční zpráva Vinařského fondu za rok 2016. Brno: Vinařský fond. Retrieved from http://vinarskyfond.cz/wpcontent/uploads/2017/05/VZ-Vinarsky-fond2016-web.pdf.

Treloar, P., Hall, C. M., \& Mitchell, R. (2004). Wine tourism and the generation $Y$ market: any possibilities?. Presented at the CAUTHE 2004: Creating Tourism Knowledge. 1-27.

Veselá, J., \& Zich, R. (2015). The Country-of-Origin Effect and its Influence on Consumer's Purchasing Decision. Acta Universitatis Agriculturae et Silviculturae Mendelianae Brunensis, 63(2), 667-673. http://doi.org/10.11118/actaun201563020667.

VinIntell. (2013). Future Scenarios for the South African Wine Industry: Part 5 - Generation $Y$ : the new market colossus. SAWIS. Retrieved from http://www.sawis.co.za/info/download/ VinIntell_June_2013_part_5_issue_16.pdf.

Ing. Jana Němcová Tomas Bata University in Zlín Faculty of Management and Economics Department of Management and Marketing Czech Republic jnemcova@utb.cz

doc. Ing. Pavla Staňková, Ph.D. Tomas Bata University in Zlín Faculty of Management and Economics Department of Management and Marketing Czech Republic stankova@utb.cz 


\title{
Abstract
}

\section{FACTORS INFLUENCING CONSUMER BEHAVIOUR OF GENERATION Y ON THE CZECH WINE MARKET}

\author{
Jana Němcová, Pavla Staňková
}

Consumer behaviour of Generation $Y$ on the wine market is currently a topical issue. Generation $Y$ is considered to be the future loyal consumers of wine and is therefore the future of the wine market. Wine-growing has a long tradition in the Czech Republic and, in particular, Moravian wines reach world level, as evidenced by a number of different awards and successes at winemaking competitions. The main aim of this paper is to identify the factors that affect the consumers of Generation $Y$ when buying wine in the Czech Republic. The target group consists of respondents aged 18-25 who drink or at least buy wines. Primary data collection took place between February and September 2017 and was realized by a questionnaire survey. In total, 648 responses were collected. The Two-sample $t$-Test and the Pearson's chi-squared $X^{2}$ test were used for statistical methods. Research has shown that young consumers clearly prefer white wine and their knowledge of wine is general for the large majority of respondents. The most common places of purchase are wine shops and supermarkets, and most of the respondents buying wines for meeting with friends, quiet sitting at home or for celebrations. Information about wine is obtained by young consumers most often from their families or friends, or from the operator in the wine shop. The most important factors for wine selection are previous purchase experience and references from family and friends, and then the information on a label, recommendations of the wine shop operator, price and colour of wine. Based on a comparison of the examined foreign sources in this area, it can be stated that wine consumers of Generation $Y$ are not a homogeneous segment and more attention should be paid to the preferences of these young people.

Keywords: Consumer behaviour, Generation Y, wine, wine factors, the Czech Republic.

JEL Classification: G34, M12.

DOI: 10.15240/tul/001/2019-4-010 